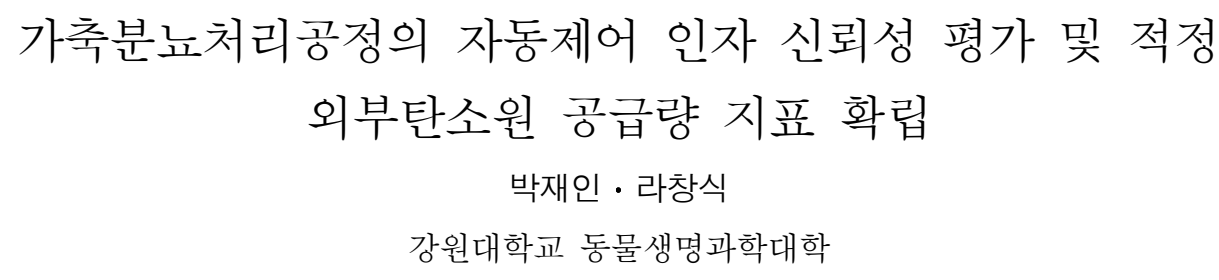

\title{
Estimation of Reliability of Real-time Control Parameters for Animal Wastewater Treatment Process and Establishment of an Index for Supplemental Carbon Source Addition
}

Jae In Pak and ChangSix Ra

College of Animal Life Science, Kangwon National University, Chunchon 200-701, Korea

\begin{abstract}
Responses of real-time control parameters, such as $\mathrm{ORP}$, DO and $\mathrm{pH}$, to the conditions of biological animal wastewater treatment process were examined to evaluate the stability of real-time control using each parameter. Also an optimum index for supplemental carbon source addition based on $\mathrm{NO}_{\mathrm{x}}-\mathrm{N}$ level was determined under a consideration of denitrification rate by endogenous respiration of microorganism and residual organic matter in liquor. Experiment was performed with lab-scale sequencing batch reactor (SBR) and working volume of the process was 45L. The distinctive nitrogen break point (NBP) on ORP-and DO-time profiles, which mean the termination of nitrification, started disappearing with the maintenance of low $\mathrm{NH}_{4}-\mathrm{N}$ loading rate. Also the NBP on ORP-and DO-time profiles was no longer observed when high $\mathrm{NO}_{\mathrm{x}}-\mathrm{N}$ was loaded into the reactor, and the sensitivity of ORP became dull with the increase of $\mathrm{NO}_{\mathrm{x}}-\mathrm{N}$ level. However, the distinctive NBP was constantly occurred on $\mathrm{pH}(\mathrm{mV})$-time profile, maintaining unique profile patterns. This stable occurrence of NBP on $\mathrm{pH}(\mathrm{mV})$-time profile was lasted even at very high $\mathrm{NO}_{\mathrm{x}}-\mathrm{N}: \mathrm{NH}_{4}-\mathrm{N}$ ratio (over 80:1) in reactor, and the specific point could be easily detected by tracking moving slope change (MSC) of the curve. Revelation of $\mathrm{NBP}$ on $\mathrm{pH}(\mathrm{mV})$-time profile and recognition of the realtime control point using MSC were stable at a condition of over $300 \mathrm{mg} / \mathrm{L} \mathrm{NOx-N}$ level in reactor. The occurrence of distinctive NBP was persistent on $\mathrm{pH}(\mathrm{mV})$-time profile even at a level of 10,000mg/L STOC (soluble total organic carbon) and the recognition of NBP was feasible by tracing MSC, but that point on ORP and DO-time profiles began to disappear with the increase of STOC level in reactor. The denitrfication rate by endogenous respiration and residual organic matter was about $0.4 \mathrm{mg} / \mathrm{L}$.hr., and it was found that 0.83 would be accepted as an index for supplemental carbon source addition when 0.1 of safety factor was applied.
\end{abstract}

(Key words : Nitrogen break point (NBP), ORP, pH (mV)-time profile, Sequencing batch reactor (SBR))

This study was funded by the ARPC(Agricultural R \& D Promotion Center) in Korea

Corresponding author : ChangSix Ra, Division of Animal Resource Science, Kangwon National Uniersity, Chunchon, 200-701, Korea.

Tel : (033) 250-8618, Fax : (033) 251-7719, E-mail: changsix@kangwon.ac.kr 


\section{I. 서 론}

가축분뇨는 다양한 요인들에 의해 그 성상이 매우 가변적인 특성을 지니고 있어 고정적인 시간을 적용하는 전통적인 생물학적 처리방법 을 이용할 경우 미처리 혹은 에너지 비용 낭비 등의 다양한 문제가 발생하게 된다 (Ra 등, 1999). 따라서 가축분뇨와 같이 가변적인 폐수 의 생물학적 처리를 위해서는 처리공정을 진단 하고 제어할 인자의 적용이 매우 유용하다 (Peng 등, 2006; Ra 등, 2000, 1999, 1998). 최근 10 년 동안 자동제어 및 온라인 공정 모니터링 과 관련하여 수행된 연구를 살펴보면 대부분이 ORP (Oxidation Reduction Potential), pH, DO (Dissolved Oxygen)를 모니터링 및 제어인자로 사용하고 있다. 반응조내에서의 오염물질과 각 인자의 변화유형을 추적하여 각 인자들을 이용 한 real-time control strategies가 제시되기도 하 였으며 실제 가축분뇨와 같이 가변적인 폐수를 대상으로 $\mathrm{ORP}$ 및 $\mathrm{pH}$ 를 이용한 실시간 자동제 어의 가능성과 유용성이 여러 연구자들에 의해 보고되었다 (Marsili, 2006; Peng 등, 2006; Akin 과 Ugurlu, 2005; Kim 등, 2004; Chen 등, 2002; Ra 등, 2000, 1999, 1998; Yu et al., 1997).

Peng 등 (2006)은 A/O (anoxic-oxic) 공정을 이 용한 연구에서 호기 및 무산소 zone에서 ORP 값과 질소의 상관관계가 매우 높아 질소원의 간접지시계로서 $\mathrm{ORP}$ 의 사용이 가능하다고 보 고한바 있으며 Ra 등(1998, 1999, 2000)과 Kim 등(2004)은 낮은 $\mathrm{C} / \mathrm{N}$ 비의 가변적 돈사폐수를 처리하는데 있어서 $\mathrm{ORP}$ 와 $\mathrm{pH}$ 를 자동제어인자 로 사용함에 의해 처리시스템의 효율증진과 에 너지 절감이 가능하였다고 보고한바 있다. 또 한 돈사폐수를 처리하는 $\mathrm{SBR}$ 공정에서 $\mathrm{ORP}$ 와 $\mathrm{pH}$ profile를 모니터링 하여 각 제어인자의 효 율을 조사한 결과 (Kishida 등, 2003), 외부탄소 원의 미사용으로 인해 반응조내 nitrate 농도가 $60 \mathrm{mg} / \mathrm{L}$ 정도로 축적되는 조건에서도 $\mathrm{ORP}$ 와 $\mathrm{pH}$ profile상에서 질산화의 완료를 의미하는 제 어점이 뚜렷하게 나타나는 것으로 보고된바 있 다. $\mathrm{ORP}$ 나 $\mathrm{pH}$ 를 공정 모니터링이나 자동제어 에 활용한 연구를 보면 대부분 $\mathrm{NH}_{4}-\mathrm{N}$ 의 질산
화가 완료되는 시점과 $\mathrm{NO}_{\mathrm{x}}-\mathrm{N}$ 의 탈질완료시점 이 $\mathrm{ORP}$ 와 $\mathrm{pH}$ 커브에서 잘 나타나는 것으로 보 고되고 있다(Zhang 등, 2006). Marsili-Libelli (2006)에 의하면 호기적 공정에서 $\mathrm{pH}$ profile의 발현은 주로 두 가지 유형으로 나타나는데 만 약 미생물에 의한 인 섭취가 질산화 완료 전에 이루어지면 $\mathrm{pH}$-time profile상에서 질산화 완료 를 의미하는 NBP (Nitrogen Break Point)가 뚜렷 하게 나타나지만 인 섭취완료 전에 질산화과정 이 완료되는 경우에 있어서는 pH-time profile상 에서 NBP를 발견하기 어렵다고 보고하고 있다. 반면 Yu et al. (1997)과 Ra 등 (1999)의 연구 결 과에서는 P-uptake에 관계없이 $\mathrm{pH}$-time profile상 에서 $\mathrm{NH}_{4}-\mathrm{N}$ 의 질산화 완료시점에 안정적으로 $\mathrm{NBP}$ 가 발현하는 것으로 보고되고 있다. 또한 반응조 운전에 있어서 질소의 부하량과 aeration rate 혹은 OUR (oxygen uptake rate)의 균형이 맞지 않는 경우에 있어서의 $\mathrm{DO}, \mathrm{ORP}$ 및 $\mathrm{pH}$-time profile 변화분석 결과(김원용 등, 2004) 질소 부하량과 포기량 및 질산화 미생물 의 산소소모율의 균형이 제대로 조절되지 못하 는 경우 DO 및 ORP-time profile의 특이적인 변 화 패턴을 이용한 호기공정의 자동제어는 신뢰 하기 어려운 것으로 나타난 반면 $\mathrm{pH}$-time profile을 이용한 자동제어는 신뢰할 수 있는 것 으로 보고된바 있다.

$\mathrm{ORP}$ 나 $\mathrm{pH}$ 를 이용한 실시간 자동제어는 처리 공정내의 오염물질의 변화를 잘 반영하는 전형 적인 $\mathrm{ORP}$ 혹은 $\mathrm{pH}$-time profile을 이용하는 것 으로서 우선적으로 안정적인 $\mathrm{ORP}$ 와 $\mathrm{pH}$ 커브 발현과 noise의 제거가 매우 중요하다. 그러나 실시간 자동제어기술을 적용한 연구 중 종종 전형적으로 발현되던 $\mathrm{ORP}$ 와 $\mathrm{pH}$-time profile이 사라지거나 변형되는 경우가 발생하는데 이러 한 요인에 의해 비록 ORP, DO, pH-time profile 의 특이적인 패턴을 이용한 실시간 자동제어 기술이 생물학적 오염물질 제거공정 (BNR, biological nutrient removal)에 적용되어 오고 있 으나 성공사례가 많이 보고되고 있지는 못하 다. 더욱이 가축분뇨처리공정에 있어서 폐수의 성상은 매우 가변적이고 이에 따라 폐수 유입 후 반응조내의 $\mathrm{C}, \mathrm{N}$ 의 수준과 성상이 크게 변 
화할 수 있기 때문에 그리고 반응조내의 환경 변화에 따라 미생물의 활성이 변화하기 때문에 $\mathrm{DO}, \mathrm{ORP}$ 및 $\mathrm{pH}$ 를 제어인자로 이용한 자동제 어를 위해서는 다양한 반응조 조건에서의 각 인자들의 time-profile 변화의 체계적인 연구가 필요하다.

생물학적 질소제거 메카니즘을 살펴보면 호 기적 단계에서 Nitrosomonas 및 Nitrobacter 미 생물들에 의해 분뇨중 $\mathrm{NH}_{4}{ }^{+}$이 $\mathrm{NO}_{2}{ }^{-}$와 $\mathrm{NO}_{3}{ }^{-}$으 로 산화된(질산화반응) 후 무산소 단계에서 여 러종의 heterotrophs에 의해 $\mathrm{NO}_{3}{ }^{-} \rightarrow \mathrm{NO}_{2}{ }^{-} \rightarrow$ $\mathrm{NO} \rightarrow \mathrm{N}_{2} \mathrm{O} \rightarrow \mathrm{N}_{2}$ 로 환원 (탈질반응)되면서 대 기로 방출되어 최종적으로 질소제거가 이루어 지게 된다. 따라서 가축분뇨내 $\mathrm{NH}_{4}-\mathrm{N}$ 을 생물학 적으로 제거하기 위해서는 질산화 과정을 위한 호기적 조건과 탈질반응을 위한 무산소 조건의 제공이 필수적이다. 또한 탈질반응에 관여하는 미생물들의 경우 최종 전자 수용체인 $\mathrm{NO}_{3}{ }^{-}$를 $\mathrm{N}_{2}$ 로 환원시키기 위해서 에너지원으로 유기물 을 필요로 하기 때문에 효율적인 생물학적 탈 질반응 유도를 위해서는 충분한 탄소원의 존재 가 필수적이다. 그러나 축산 분뇨의 경우 $\mathrm{C} / \mathrm{N}$ 비가 낮을 뿐만아니라 호기적 질산화 반응에서 유기물의 산화도 동시에 일어나기 때문에 탈질 단계에서 에너지원으로 이용될 유기물이 부족 하게 되며 탈질효율은 주로 에너지원으로 이용 될 가용 유기물량에 따라 달라진다. 따라서 대 부분의 생물학적공정에서 탈질효율을 높이기 위해 에너지원으로 methonol, glucose, acetate 등 의 고비용의 추가 탄소원이 이용되고 있으며 운전비용의 상당량을 차지하고 있는 실정이다. 따라서 자체 잔존 유기물과 미생물 자기산화에 의한 탈질율을 구명하여 추가탄소원의 사용량 을 최소화 하기 위한 연구 및 그 결과의 활용 은 큰 의의가 있을 것으로 판단된다.

이에 본 논문에서는 $\mathrm{DO}, \mathrm{ORP}$ 및 $\mathrm{pH}$-time profile을 이용한 호기공정의 자동제어 신뢰성을 추가로 확보/평가하기 위하여 실제 현장에서 흔히 목격되는 다양한 조건을 제공하고 각 제 어인자의 반응을 분석하였다. 시험된 조건은 이전 처리단계에서 대부분의 질산화가 이루어 지는 등의 다양한 원인에 의해 반응조로의
$\mathrm{NH}_{4}-\mathrm{N}$ 의 부하가 매우 낮은 경우, 반응조내에 $\mathrm{NO}_{\mathrm{x}}-\mathrm{N}$ 이 지속적으로 축적되는 경우 혹은 $\mathrm{NO}_{\mathrm{x}}$ $\mathrm{N}$ 의 농도가 매우 높은 유입수가 유입되는 경 우 및 반응조내에서 유기물의 농도가 지속적으 로 증가하는 상황에서의 각 제어인자별 time profile의 변화를 분석하여 호기적 공정의 실시 간 자동제어를 위한 인자의 신뢰성을 최종 평 가하였다. 또한 무산소 조건에서의 잔존 유기 물과 endogenous respiration에 의한 탈질율 및 $\mathrm{TOC} / \mathrm{NO}_{\mathrm{x}}-\mathrm{N}$ 비에 따른 탈질양상을 파악하여 $\mathrm{NO}_{\mathrm{x}} \mathrm{-N}$ 의 농도를 기준으로 한 적정 외부탄소원 공급량 지표를 확립하고자 하였다.

\section{․ 재료 및 방법}

\section{1. 시스템 설비 및 운전방법}

On-Line 모니터링 시스템을 갖춘 실험실 규 모의 SBR 공정을 Fig. 1에 나타내었다. SBR은 아크릴로 제작되었으며 유효용적은 $45 \mathrm{~L}$ 이었다. 반응조 내용물의 완전한 혼합을 위해 기계적 교반장치가 반응조내에 설비되었으며 공기의 공급은 반응조 바닥에 놓인 수족관용 산기관을 통해 이루어지도록 하였다.

제어인자들의 실시간 모니터링을 위해 $\mathrm{ORP}$ (Ag/AgCl reference), $\mathrm{pH}, \mathrm{DO}$ probe가 반응조내 에 삽입되었으며 전기적 신호의 정확한 계측을 위해 electric isolator와 연결되었다. 전기적 신 호는 케이블 리본을 통해 아날로그/디지털 변 환장치가 설비된 컴퓨터로 전달되도록 하였다. 전기적 신호는 1 분 간격으로 자동 모니터링 되 도록 프로그램 하였으며 시스템을 다양한 공정

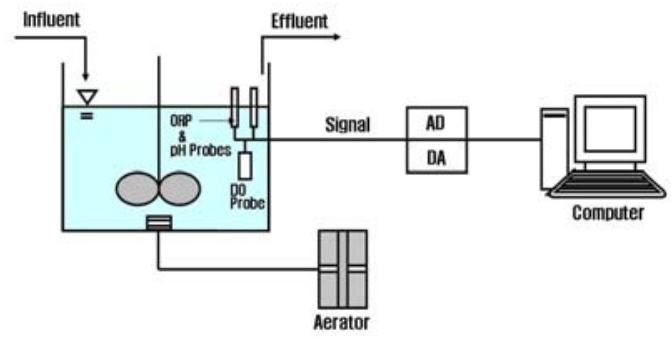

Fig. 1. Schematic diagram of experimental apparatus. 
에서 운전하면서 각 제어인자들의 발현 양상과 안정성을 분석하였다.

$\mathrm{SBR}$ 공정은 r가축분뇨유입 $\rightarrow$ 호기과정 $\rightarrow$ 무 산소과정 $\rightarrow$ 침전 $\rightarrow$ 배출」의 순서로 운전되었 으며 호기과정과 무산소과정의 시간은 목적된 조건에서의 제어인자들의 반응을 추적/분석하 기 위하여 수시로 변화시켰다.

$\mathrm{NO}_{\mathrm{x}}-\mathrm{N}$ 농도에 따른 $\mathrm{ORP}, \mathrm{DO}$ 및 $\mathrm{pH}(\mathrm{mV})-$ time profile 변화 분석시험에서는 매우 낮은 $\mathrm{NH}_{4}-\mathrm{N}$ 부하량인 $4.5 \mathrm{~g} / \mathrm{m}^{3}$ - cycle 조건하에서 운 전하면서 반응조내 $\mathrm{NO}_{\mathrm{x}} \mathrm{-N}$ 농도 변화와 $\mathrm{ORP}$, $\mathrm{DO}, \mathrm{pH}(\mathrm{mv})$ profile의 변화를 모니터하였으며 빠른 $\mathrm{NO}_{\mathrm{x}} \mathrm{-N}$ 농도 변화를 유도하기 위하여 돈 사폐수 유입시 $\mathrm{KNO}_{3}$ 용액시약을 매 cycle 당 $3.125 \mathrm{~g} / \mathrm{m}^{3}$ 첨가하였다. 유기물 농도가 ORP 및 $\mathrm{pH}(\mathrm{mV})$ 에 미치는 영향분석 시험에서는 다양한 유기물 농도 조건하에서의 자동제어 인자의 변 화를 모니터하기 위하여 폐수 유입시 glucose 액의 첨가량을 달리하여 반응조내의 STOC 농 도를 변화시켰으며 $\mathrm{NH}_{4}-\mathrm{N}$ 의 농도는 $5 \mathrm{mg} / \mathrm{L}$ 이 하를 유지하도록 하였다.

\section{2. 돈사폐수 및 분석방법}

돈사폐수는 농장으로부터 수집되어 $0.5 \mathrm{~mm}$ 채로 스크린 한 후 냉장실에 보관하면서 시험 에 사용하였다.

분석항목은 STOC (soluble total organic carbon), $\mathrm{NH}_{4}-\mathrm{N}, \mathrm{NO}_{\mathrm{x}}-\mathrm{N}$ 이었다. STOC는 샘플을 필터링한 후 TOC 자동 분석기 (model TOC-5000A, Shimadzu) 를 이용하여 분석하였고 $\mathrm{NH}_{4}-\mathrm{N}$ 와 $\mathrm{NO}_{\mathrm{x}}-\mathrm{N}$ 는 자 동수질분석기 (automatic wastewater analyzer, model Quikchem 8000, Zellweger)를 이용하여 분석하 였다.

$\mathrm{SBR}$ 공정의 초기가동을 위해 돈사폐수를 처 리하고 있는 파일럿 규모(20톤)의 SBR 공정으 로부터 활성슬러지를 취한 후 제작된 SBR 반 응조에 접종하고 정상 조건하에서 운전하면서 공정의 안정화가 이루어졌을 때 실험을 진행하 였다.

\section{III. 결과 및 고찰}

\section{1. 질소원에 대한 제어인자 반응}

하나 이상의 생물학적 처리공정으로 구성된 가축분뇨 처리공정에서 낮은 질소 부하량 유지 및 이전단계 처리공정에서의 매우 활발한 질산 화 반응으로 인해 주 처리공정으로 고농도의 $\mathrm{NO}_{\mathrm{x}}-\mathrm{N}$ 을 함유한 폐수가 유입되거나 혹은 탈질 반응의 저하로 반응조내에 $\mathrm{NO}_{\mathrm{x}}-\mathrm{N}$ 이 지속적으 로 축적되는 경우에 있어서의 자동제어 인자들 의 반응 및 그 발현양상을 분석하기 위하여 $\mathrm{NH}_{4}-\mathrm{N}$ 의 부하량을 매우 낮은 수준인 $4.5 \mathrm{~g} / \mathrm{m}^{3}$. cycle 수준으로 유지하고 $\mathrm{NO}_{3}$ 농도를 달리하면 서 반응조내 질소원 농도 변화에 따른 $\mathrm{ORP}$ 와 $\mathrm{pH}(\mathrm{mV})$-time profile 패턴변화를 시험하였다(Fig. 2, 3, 4). Fig. 2는 $\mathrm{NO}_{\mathrm{x}}-\mathrm{N} / \mathrm{NH}_{4}-\mathrm{N}$ 의 비가 1:1 8:1 (10이하) 범위에서의 profile 패턴이며 3과 4는 각각 $10: 1 \sim 40: 1,40: 1 \sim 80: 1$ 범위에서의 패턴 변 화를 나타낸 것이다.

Fig. 2a,b의 첫 번째 cycle에서와 같이 전형적 으로 완전 질산화가 일어나는 시점에서 $\mathrm{ORP}$ 와 $\mathrm{DO}$ curve는 갑작스럽게 상승하게 되며 $\mathrm{pH}$ $(\mathrm{mV})$ curve는 하락하게 된다. 1st cycle에서 $\mathrm{NH}_{4}-\mathrm{N}$ 부하량과 폭기량의 균형 및 충분한 무 산소 조건의 제공으로 $\mathrm{ORP}$ 와 $\mathrm{pH}$ 및 $\mathrm{DO}$ curve 상에서 $\mathrm{NBP}$ 가 뚜렷하게 발현되던 중 $\mathrm{NH}_{4}-\mathrm{N}$ 의 낮은 부하와 $\mathrm{NO}_{3}$ 를 함유한 폐수 유입 및 불충 분한 무산소 조건 제공이 이루어졌을 때 2 4번 째 curve에서와 같은 변화가 일어나기 시작하 였다. 낮은 $\mathrm{NH}_{4}-\mathrm{N}$ 부하량 유지로 호기적 처리 조건에서 빠르게 완전 질산화가 이루어졌을 때 $\mathrm{ORP}$ 와 DO curve 상에서는 $\mathrm{NBP}$ 가 발현되지 않 기 시작하였으며 불충분한 탈질로 인해 반응조 내에 $\mathrm{NO}_{\mathrm{x}}-\mathrm{N}$ 이 축적되고 또한 feeding시 $\mathrm{NO}_{3}$ 를 함유한 폐수가 유입됨에 의해 반응조내 $\mathrm{NO}_{\mathrm{x}}-\mathrm{N}$ 의 농도가 점차 증가함에 따라 $\mathrm{ORP}$ 값의 변화 폭이 크게 감소하였다. Cycle 2 4에서와 같이 완전 질산화가 이루어짐에도 $\mathrm{ORP}$ 와 $\mathrm{DO}$ 상에서 


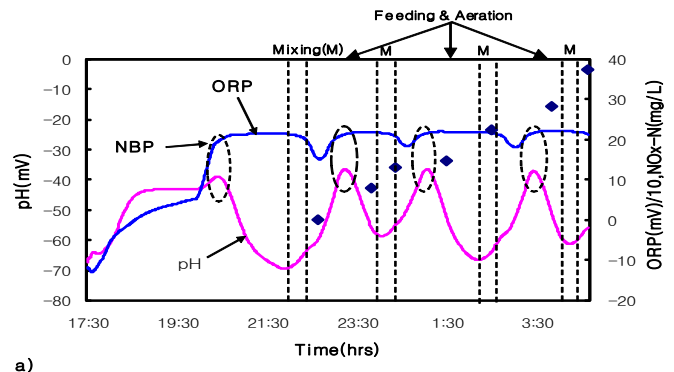

a)
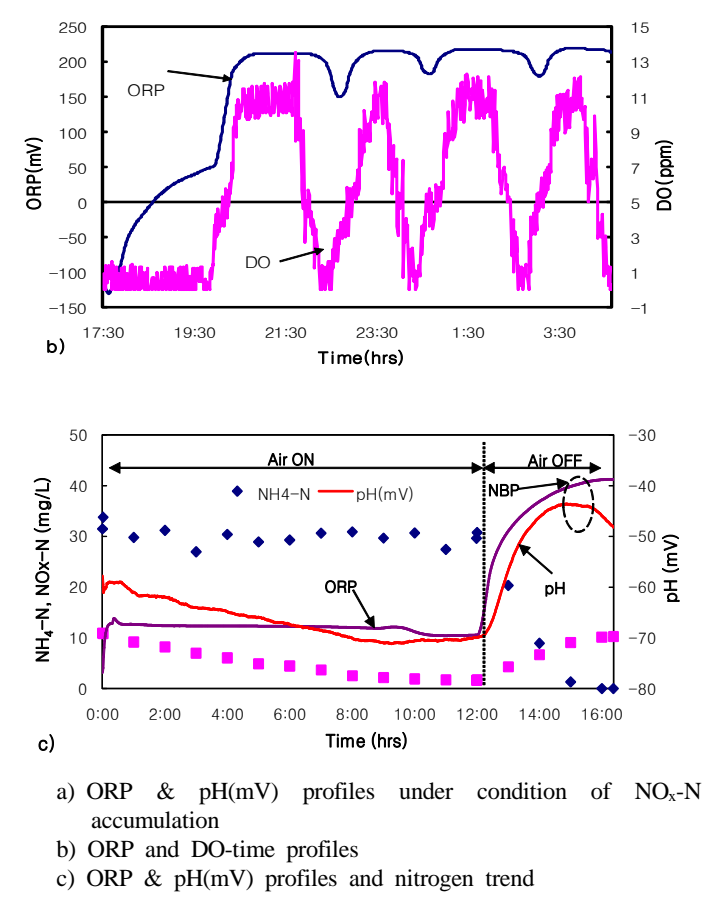

Fig. 2. Profiles of control parameters and nitrogen.

$\mathrm{NBP}$ 가 뚜렷하게 발현되지 않은 것은 폭기의 시작과 더불어 $\mathrm{DO}$ 농도가 빠르게 증가하는 과 정 중에 완전질산화 반응이 일어났기 때문이며 이러한 $\mathrm{NBP}$ 의 masking 현상은 $\mathrm{ORP}$ 의 $\mathrm{O}_{2}$ 에 민 감성에 의한 것으로 판단된다. 또한 낮은 $\mathrm{NH}_{4}-\mathrm{N}$ 부하량 유지로 인해 포기율이 질산화 미생물의 산소소모량 (Oxygen Uptake Rate, OUR) 보다 과도하게 높아짐에 따라 ORP 커브 상에 서 이러한 NBP masking 현상이 발생한 것으로 판단된다.

그러나 $\mathrm{pH}(\mathrm{mV})$ 커브는 $\mathrm{NO}_{\mathrm{x}}-\mathrm{N}$ 의 농도 증가 및 낮은 $\mathrm{NH}_{4}-\mathrm{N}$ 부하량 유지와 상관없이 항상
일정한 변화패턴을 유지하였으며 완전질산화가 이루어졌을 때 뚜렷한 NBP가 발현됨을 알 수 있었다. $\mathrm{pH}(\mathrm{mV})$-time profile을 살펴보면 폐수 유입후 주어진 호기적 조건에서 포기와 더불어 $\mathrm{pH}(\mathrm{mV})$ 값이 서서히 증가하다가 어느 시점에 서 감소하기 시작하는 일정한 커브패턴을 나타 내는데 이 시점이 $\mathrm{NBP}$ 로서 반응조내에 존재하 는 암모니아성 질소의 완전 질산화가 이루어진 시점을 나타내는 것이다.

Fig. 2c는 무산소 및 호기조건에서의 ORP 및 $\mathrm{pH}(\mathrm{mV})$-time profile과 반응조내 질소원 변화를 나타낸 것으로 무산소 조건에서 $\mathrm{NO}_{\mathrm{x}}-\mathrm{N}$ 의 탈질 이 진행됨에 따라 $\mathrm{pH}(\mathrm{mV})$ 커브는 점차 감소한 반면 ORP 커브에서는 아무런 변화가 나타나지 않았다. 무산소 조건에서의 $\mathrm{pH}(\mathrm{mV})$ 값의 점차 적인 하락은 $\mathrm{NO}_{\mathrm{x}}-\mathrm{N}$ 의 탈질로 인해 alkalinity가 회복되었기 때문으로 판단된다. 무산소 조건에 서의 ORP curve는 탈질시 일정한 값을 유지하 거나 혹은 약간의 증가 혹은 감소의 변화를 나 타내다가 $\mathrm{NO}_{\mathrm{x}}-\mathrm{N}$ 이 0 이 되는 시점, 즉 탈질 종 료시점 (NKP)에 매우 큰 폭으로 하락하는데 본 그래프에서는 $\mathrm{NO}_{\mathrm{x}} \mathrm{-N}$ 의 완전한 탈질이 이루어 지지 않아 이러한 변화 양상을 관찰할 수 없었 다.

무산소조건 후 포기가 시작됨에 따라 활발한 질산화 과정이 일어나 약 3.5 시간 만에 완전 질산화되어 $\mathrm{NH}_{4}-\mathrm{N}$ 의 농도가 고갈되었으며 $\mathrm{NO}_{\mathrm{x}}$ $\mathrm{N}$ 의 농도는 plateau를 나타내기 시작하였다. $\mathrm{ORP}$ 와 $\mathrm{pH}(\mathrm{mV})$-time profile을 살펴보면 호기과 정의 시작으로 커브가 매우 빠르게 증가하다가 $\mathrm{NH}_{4}-\mathrm{N}$ 의 농도가 zero에 다다른 시점 즉 $\mathrm{NH}_{4}-\mathrm{N}$ 의 완전 질산화가 이루어진 시점에 $\mathrm{pH}(\mathrm{mV})$ curve가 서서히 하락하는 전형적인 NBP가 발현 되었으나 ORP 커브 상에서는 아무런 변화가 관찰되지 않았다. 이러한 결과는 Fig. 2, 3, 4의 $\mathrm{pH}(\mathrm{mV})$-time profile에서 나타난 bending point 가 실제 $\mathrm{NBP}$ 이었음을 나타낸다. 또한 이러한 결과는 질소 부하량 변동, 미생물 활성변화, 계 절적 온도변화에 따른 산소 전달량의 변동 등 
에 따른 포기량 균형유지 실패 및 다양한 단위 공정으로 구성된 공정에서 흔히 직면되는 여러 문제발생 시에도 $\mathrm{pH}(\mathrm{mV})$-time profile의 모니터 링을 통해 질산화가 완전히 종료되는 시점을 안정적으로 인식할 수 있는 반면 ORP나 $\mathrm{DO}$ 의 모니터링으로는 불가능함을 나타내는 것이라 할 수 있다.

$\mathrm{NO}_{\mathrm{x}}-\mathrm{N} / \mathrm{NH}_{4}-\mathrm{N}$ 의 비가 10:1 40:1, 40:1 80:1 범 위에서의 curve 패턴 변화를 분석한 결과 (Fig. 3 과 4) 앞 데이터와 마찬가지로 $\mathrm{ORP}$ 와 $\mathrm{DO}-$ time profile에서는 완전 질산화 종료시점 (NBP) 을 발견할 수 없었다. 반면 $\mathrm{pH}(\mathrm{mV})$-time profile 에서는 지속적이고 안정적인 $\mathrm{NBP}$ 의 발현을 확 인할 수 있었으며 $\mathrm{pH}(\mathrm{mV})$-time profile에서 발 현되는 NBP는 Moving Slope Change (MSC)의 변화 패턴을 추적함에 의해 실시간으로 인식할 수 있었다. Fig. 3c와 4c는 지난 10 분간의 $\mathrm{pH}$ $(\mathrm{mV})$ 값 변화의 기울기를 매 1 분 간격으로 모 니터한 MSC 그래프와 $\mathrm{pH}(\mathrm{mV})$ curve에서 발현 하는 $\mathrm{NBP}$ 를 실시간으로 인식하는 기법을 나타 내는 것이다. $\mathrm{pH}(\mathrm{mV})$ curve 상에서의 발현되는 $\mathrm{NBP}$ 는 $\mathrm{MSC}$ 를 모니터링 함에 의해 실시간으로 확인할 수 있었는데 폐수 유입 후 호기조건에 서 positive peak 발현 후 negative peak로 접어 들 때가 바로 그 시점이다. $\mathrm{pH}(\mathrm{mV})$-time profile 을 이용한 호기 조건의 자동제어를 위한 알고 리즘 구성으로는 호기조건에서 1 분 간격으로 모니터된 MSC가 +4 이상의 값을 나타내는지의 여부를 먼저 인지한 후 단계적으로 -2 이하의 값을 가지는 시점을 인지하도록 하는 것이 효 율적일 것으로 판단되었다. $\mathrm{pH}(\mathrm{mV})$-time profile 에서의 $\mathrm{NBP}$ 의 발현과 $\mathrm{MSC}$ 를 이용한 실시간 자동제어시점 인지는 반응조내 $\mathrm{NO}_{\mathrm{x}} \mathrm{-N}$ 농도가 매우 높은 $300 \mathrm{mg} / \mathrm{L}$ 수준을 나타냄에도 안정적 이었다.

이러한 결과로 미뤄 이전 사이클에서 $\mathrm{NO}_{\mathrm{x}} \mathrm{-N}$ 의 완전 탈질이 이루어지지 않아 반응조내에 $\mathrm{NO}_{\mathrm{x}}-\mathrm{N}$ 의 농도가 증가하는 경우나 혹은 이전 처리공정으로부터 $\mathrm{NO}_{\mathrm{x}}-\mathrm{N}$ 의 농도가 높은 유입
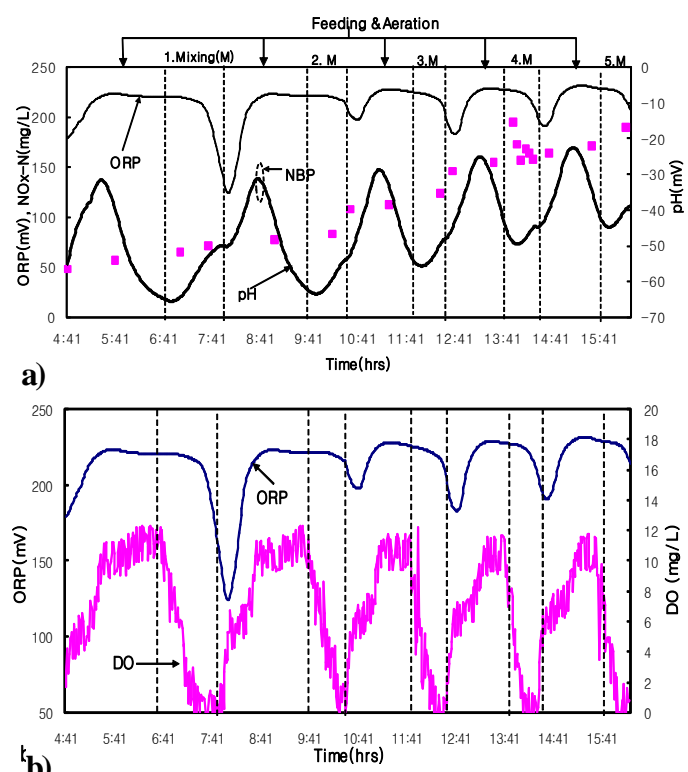

b)

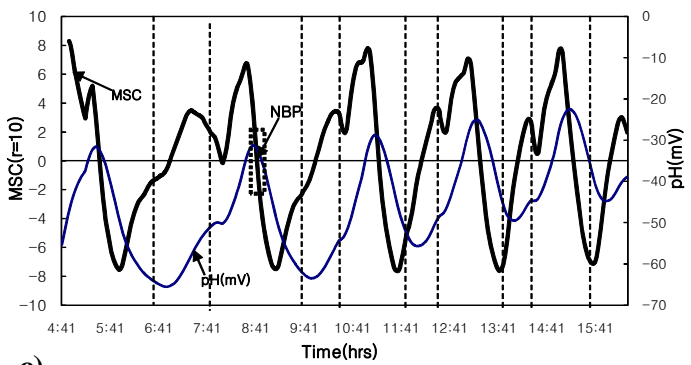

(c)

a) ORP \& $\mathrm{pH}(\mathrm{mV})$ profiles under condition of $\mathrm{NO}_{\mathrm{x}}-\mathrm{N}$ accumulation

b) ORP and DO-time profiles

c) Pattern of moving slope change (MSC) of $\mathrm{pH}(\mathrm{mV})$-time profile

Fig. 3. Profiles of parameters and control strategy.

수가 loading 되는 경우 또는 여러 요인에 의해 반응조로 $\mathrm{NH}_{4}-\mathrm{N}$ 의 loading이 적은 경우 $\mathrm{ORP}$ 와 $\mathrm{DO}$ 를 이용한 질산화과정의 자동제어 및 진단 에는 오류가 발생함을 알 수 있었다. 또한 ORP 값과 ORP-time profile 패턴은 $\mathrm{DO}$ 의 농도뿐만 아니라 반응조내 $\mathrm{NOx}-\mathrm{N}$ 의 농도에 의해서도 크 게 영향을 받는 것으로 나타났다. Fig. 2와 3, 4 에서 각 cycle에서 무산소조건 동안의 ORP 값 의 변화와 ORP-time profile의 변화를 보면 DO 의 농도가 zero 수준일 때에도 ORP값은 큰 하 

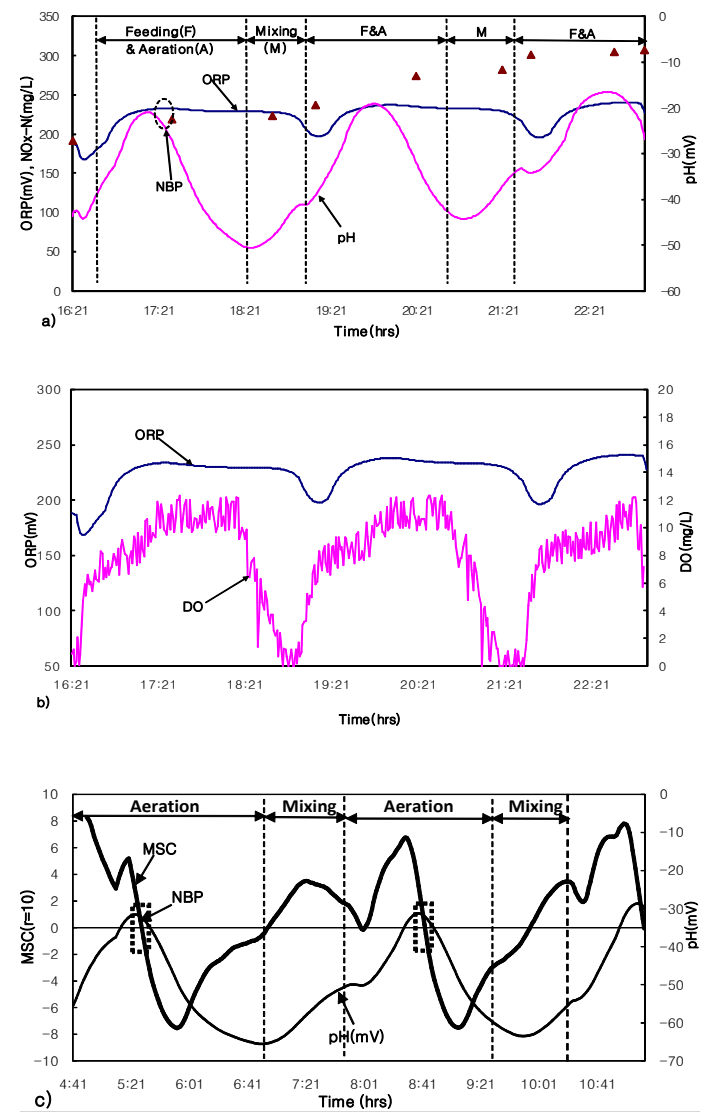

a) ORP \& $\mathrm{pH}(\mathrm{mV})$ profiles under condition of $\mathrm{NO}_{\mathrm{x}}-\mathrm{N}$ accumulation

b) ORP and DO-time profiles

c) Pattern of MSC of $\mathrm{pH}(\mathrm{mV})$-time profile

Fig. 4. Profiles of parameters and control strategy.

락을 보이지 않으며 매우 높은 값인 200 230 $\mathrm{mV}$ 수준을 유지하는데 이는 ORP의 산소에 대 한 민감성이 $\mathrm{NO}_{\mathrm{x}} \mathrm{-N}$ 이 존재하는 조건하에서는 감소하게 되며 $\mathrm{NO}_{\mathrm{x}} \mathrm{-N}$ 의 농도가 고농도일 때는 $\mathrm{O}_{2}$ 에 대한 특이적인 변화를 나타내지 못하는 특성 때문인 것으로 판단된다. 폐수처리 공정 에서 모니터된 $\mathrm{ORP}$ 값은 주로 $\mathrm{DO}$ 농도와 정 비례하나 DO 농도가 zero가 되었을 때에는 주 로 반응조내 NOx-N 농도에 의해 좌우되는 것 으로 알려지고 있다 (Akin과 Ugurlu, 2005).

\section{2. 유기물에 대한 제어인자 반응}
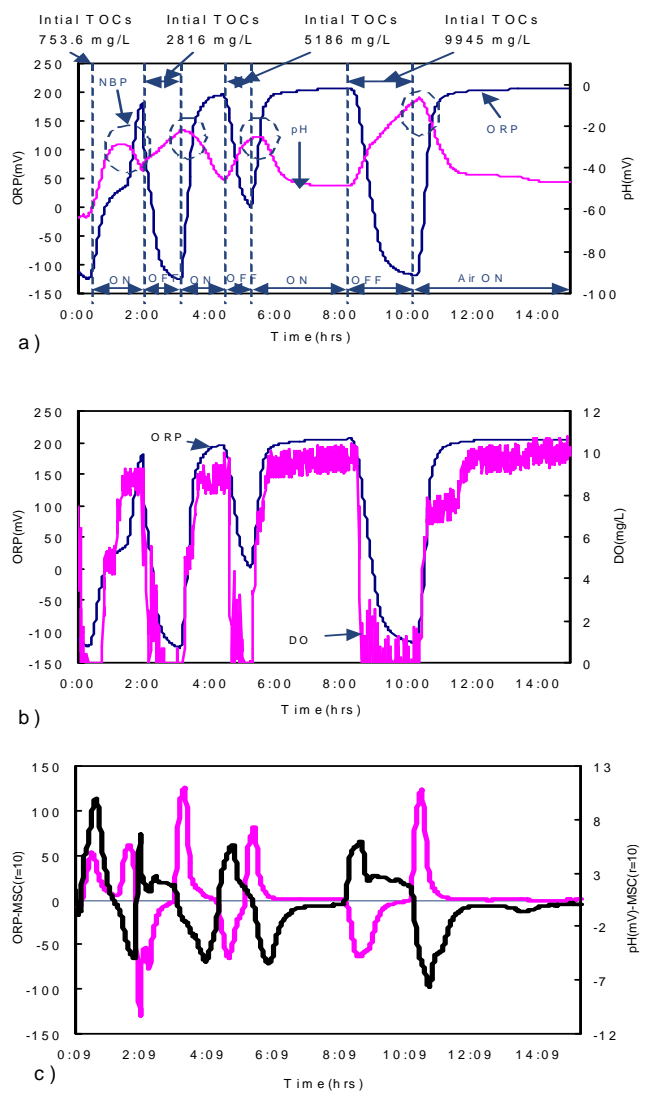

a) ORP \& $\mathrm{pH}(\mathrm{mV})$ profiles under condition of organic matter accumulation

b) ORP and DO-time profiles

c) Patterns of MSC of ORP \& pH(mv)-time profiles

Fig. 5. Profiles of parameters and control strategy.

Fig. 5는 반응조내 STOC의 농도 변화에 따른 $\mathrm{ORP}, \mathrm{pH}(\mathrm{mV})$-time profile의 변화를 분석한 것 이다. 그림의 첫 번째 사이클에서와 같이 ORP 와 $\mathrm{pH}(\mathrm{mV})$ curve상에서 정상적인 $\mathrm{NBP}$ 가 발현 되던 중 유입수내 $\mathrm{NH}_{4}-\mathrm{N}$ 의 농도를 $5 \mathrm{mg} / \mathrm{L}$ 로 유지하고 feeding 시 glucose solution을 첨가하 여 반응조내 STOC 농도를 점차 증가시켰다. 지속적인 glucose solution의 첨가로 인해 STOC 의 농도가 점차 증가하여 반응조내 STOC 농도 가 거의 $10,000 \mathrm{mg} / \mathrm{L}$ 수준으로까지 증가함에도 불구하고 $\mathrm{pH}(\mathrm{mV})$ curve 상에서는 안정적으로 $\mathrm{NBP}$ 가 발현됨을 알 수 있었다. 그러나 ORP와 $\mathrm{DO}$ curve 상에서는 암모니아성 질소의 질산화 
과정 종료를 의미하는 $\mathrm{NBP}$ 가 전혀 발현되지 않았는데 이는 앞서 설명한 것과 같이 낮은 $\mathrm{NH}_{4}-\mathrm{N}$ 농도유지로 인한 미생물의 OUR과 포기 량의 불균형 때문인 것으로 판단된다. $\mathrm{pH}(\mathrm{mV})$ curve 패턴을 분석해보면 포기시작 후 그 값이 상승하다가 감소하는 시점, 즉 $\mathrm{NBP}$ 가 발생한 후 지속적으로 하락하다가 폭기가 중지되고 무 산소 조건이 시작됨에 따라 그 값이 크게 상승 하는 것을 볼 수 있는데 이는 폭기 중지로 인 한 $\mathrm{CO}_{2}$ 의 재용해가 일어나기 때문이며 $\mathrm{ORP}$ 와 $\mathrm{pH}$ curve 변화에 대한 자세한 이론적인 설명은 이미 보고된 바 있다 (Ra 등, 1998). ORP와 $\mathrm{pH}$ $(\mathrm{mV})$ 의 MSC를 분석해보면 (Fig. 5c) $\mathrm{pH}(\mathrm{mV})$ curve에서 발현되는 NBP는 MSC 값의 변화를 모니터함에 의해 비교적 쉽게 인지될 수 있었 으며 앞의 질소에 대한 제어인자 반응 특성분 석에서와 동일한 알고리즘이 실시간 자동제어 를 위해 사용될 수 있음을 알 수 있었다. ORP$\mathrm{MSC}$ 의 경우에는 첫 번째 사이클에서와 같이 $1^{\text {st }}$ positive peak 발현 후 단계적으로 나타나는 $2^{\text {nd }}$ positive peak가 바로 질산화 종료시점 (NBP) 이다. 그러나 두 번째 사이클부터 암모니아 부 하량과 STOC 농도가 변화함에 따라 ORP curve 상에서 $\mathrm{NBP}$ 가 발현되지 않았고 이에 $2^{\text {nd }}$ positive peak가 나타나지 않았음을 알 수 있다.

이상의 결과로 미뤄 반응조내 유기물의 농도 가 점차 축적되는 상태에서, 즉 반응조내 오염 물질의 화학적 상태가 환원된 상태로 존재하여 산화환원가가 비교적 낮은 상태에서도 앞의 $\mathrm{NO}_{\mathrm{x}}-\mathrm{N}$ 영향 실험에서와 같이 $\mathrm{NBP}$ 가 $\mathrm{ORP}$ curve상에서 masking 됨을 알 수 있었다. 호기 및 무산소 조건에서의 ORP 값의 변화는 앞의 $\mathrm{NO}_{\mathrm{x}} \mathrm{-N}$ 에 대한 반응과는 달리 $\mathrm{DO}$ 값의 변화에 민감하게 반응하는 것으로 나타났다. 호기 및 무산소 조건에서의 $\mathrm{ORP}$ 값의 빠른 증가와 감 소는 $\mathrm{NO}_{\mathrm{x}}-\mathrm{N}$ 의 농도가 매우 낮아 주로 $\mathrm{DO}$ 농 도 변화에 ORP가 반응하였기 때문으로 판단된 다. 또한 포기중지 후의 빠른 $\mathrm{ORP}$ 의 감소는 반 응조내의 산화환원력 상태에 ORP가 빠르게 반
응하였기 때문으로 판단된다.

반면 반응조내 고농도 유기물 축적은 $\mathrm{pH}$ $(\mathrm{mV})$ 변화 패턴에 아무런 영향을 미치지 않았 으며 $\mathrm{pH}(\mathrm{mV})$ curve 상에서는 질산화 종료 시 점이 항상 안정적으로 발현되고 MSC 변화 패 턴을 이용하여 쉽게 NBP 시점을 인지할 수 있 음을 알 수 있었다. 유기물의 농도가 축적되는 상황하에서도 $\mathrm{pH}(\mathrm{mV})$-time profile에서의 안정 적인 $\mathrm{NBP}$ 의 발현은 제어인자 고유특성에 의한 것으로 $\mathrm{ORP}$ 의 경우에는 반응조내 산화환원력 의 변화에 반응하는 반면 $\mathrm{pH}$ 의 경우에는 주로 반응조내 alkalinity 변화에 반응하기 때문으로 판단된다. 유기물 농도의 축적으로 인한 반응 조내 산화환원력가의 감소에 상관없이 호기적 조건에서 $\mathrm{NH}_{4}-\mathrm{N}$ 의 질산화가 진행됨에 따라 약 $7 \mathrm{mg}$ alkalinity/mgNH $\mathrm{m}_{4} \mathrm{~N}$ 의 소모가 일어나게 되 며 이에 따라 $\mathrm{pH}(\mathrm{mV})$ 값이 증가하게 되고 $\mathrm{NH}_{4}-\mathrm{N}$ 의 완전 질산화가 이루어진 다음에는 alkalinity 소모가 중지되고 계속되는 포기로 인 해 $\mathrm{CO}_{2}$ stripping이 일어나 $\mathrm{pH}(\mathrm{mV})$ 값이 하락하 는 것으로 여겨진다.

Fig. 6은 반응조내 STOC 및 $\mathrm{NH}_{4}-\mathrm{N}$ 농도와 $\mathrm{ORP}, \mathrm{pH}(\mathrm{mV})$ curve의 변화를 분석한 것이다. 시험된 반응조내 초기 $\mathrm{NH}_{4}-\mathrm{N}$ 농도와 STOC 농 도는 각각 $32 \mathrm{mg} / \mathrm{L}, 6540 \mathrm{mg} / \mathrm{L}$ 이었다. 유입수 loading 후 호기적 처리과정에서의 STOC와 $\mathrm{NH} 4-\mathrm{N}$ 의 거동을 볼 때 STOC 농도는 거의 일 정한 농도를 유지하면서 많이 제거되지 않았 다. 그러나 $\mathrm{NH}_{4}-\mathrm{N}$ 는 활발한 질산화 과정에 의 해 지속적으로 감소하다가 대략 2시간이내에 $0 \mathrm{mg} / \mathrm{L}$ 가 됨을 알 수 있었다. ORP와 $\mathrm{pH}(\mathrm{mV})$ curve 패턴을 살펴보면 ORP curve의 경우 포기 시작과 더불어 상승하다가 plateau에 다다르면 서 아무런 특이적인 변화를 나타내지 않았으나 $\mathrm{pH}(\mathrm{mV})$ curve의 경우에는 포기 시작 후 curve 가 상승하다가 갑작스럽게 하락하는 특이적인 변화 양상을 보였으며 이 시점이 $\mathrm{NH}_{4}-\mathrm{N}$ 의 농 도가 $0 \mathrm{mg} / \mathrm{L}$ 가 되는 완전질산화 시점임을 알 수 있었다. 앞에 설명한 것과 같이 포기 시작 

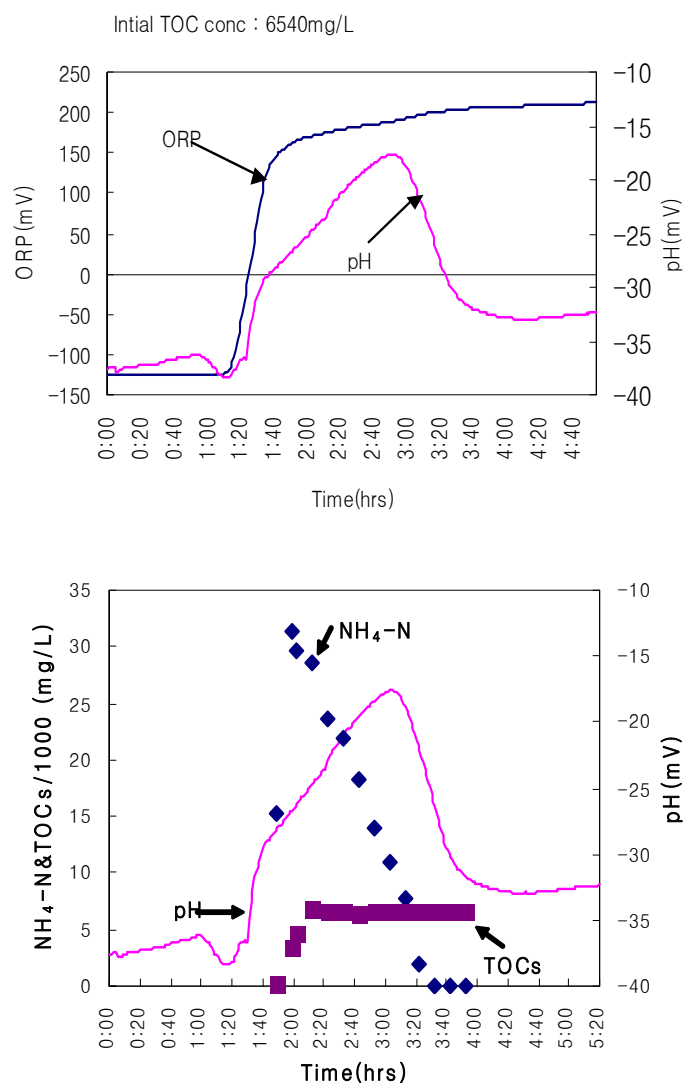

Fig. 6. Tracks of nutrient and profile patterns.

후의 $\mathrm{pH}(\mathrm{mV})$ 값의 상승은 질산화 과정에 의한 $\mathrm{NO}_{2}$ 및 $\mathrm{NO}_{3}$ 의 생성과 alkalinity의 소모에 의한 것으로 판단되며 $\mathrm{NH}_{4}-\mathrm{N}$ 이 zero가 되는 시점에 서의 $\mathrm{pH}(\mathrm{mV})$ 값의 하락은 질산화 미생물의 OUR이 $\mathrm{NH}_{4}-\mathrm{N}$ 의 질산화 종료로 인해 크게 줄 어듦에 따라 계속되는 포기로 인해 용액내 $\mathrm{CO}_{2}$ stripping이 유도되었기 때문으로 판단된다.

종합적으로 $\mathrm{NO}_{\mathrm{x}}-\mathrm{N}$ 과 유기물이 자동제어 인 자 $(\mathrm{ORP}$ 및 $\mathrm{pH}(\mathrm{mV}))$ 에 미치는 영향을 고려할 때 호기적 조건에서는 $\mathrm{pH}(\mathrm{mV})$ 가 $\mathrm{ORP}$ 보다는 반응조 환경에 유동이 적으며 안정적으로 완전 질산화 시점을 실시간으로 인지할 수 있는 자 동제어 인자라 판단된다.

\section{3. $\mathrm{NO}_{x}-\mathrm{N}$ 을 기준으로 한 적정 $\mathrm{TOC}$ 첨가량 산정}
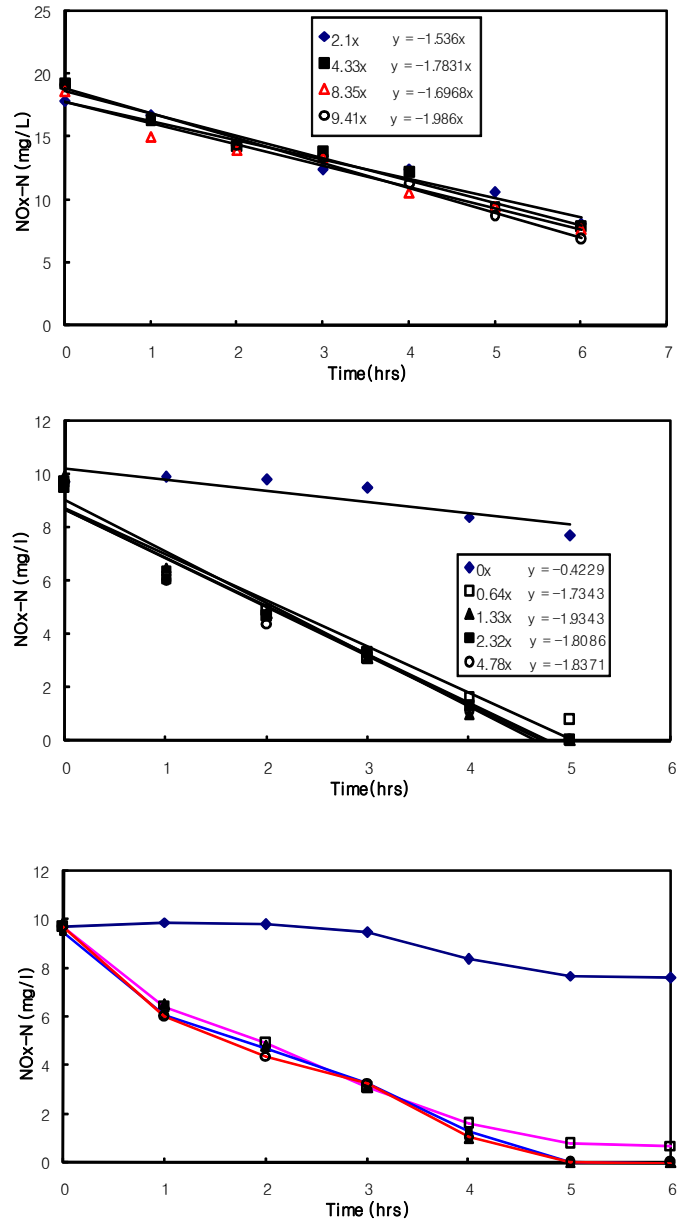

Fig. 7. Denitrification rate vs initial $\mathrm{C} / \mathrm{N}$.

무산소 조건에서의 완전탈질을 위한 적정 유 기물 첨가량을 산정하기 위하여 실제 loading된 탄소원의 $\mathrm{TOC}$ 양과 $\mathrm{NO}_{\mathrm{x}} \mathrm{-N}$ 농도를 기준으로 $\mathrm{C} / \mathrm{N}$ 비를 2.1, 4.33, 8.35, 9.41로 조절하고 6시간 동안의 탈질율을 파악하였다 (Fig. 7). 시험된 각 $\mathrm{C} / \mathrm{N}$ 비 수준에서의 $\mathrm{NO}_{\mathrm{x}} \mathrm{-N}$ 제거율은 각각 $1.5,1.7,1.7,2.0 \mathrm{mg} / \mathrm{L} . \mathrm{hr}$ 로 $\mathrm{C} / \mathrm{N}$ 변화에 따라 큰 차이를 나타내지 않은 것으로 나타났다. 이에 실제 공급된 $\mathrm{TOC}$ 와 $\mathrm{NO}_{\mathrm{x}}-\mathrm{N}$ 을 기준으로 $\mathrm{C} / \mathrm{N}$ 비 2 이상의 수준은 탈질에 충분한 것으로 판단하 고 $\mathrm{C} / \mathrm{N}$ 비를 다소 낮은 수준인 $0,0.64,1.33$, 2.32, 4.78로 조절하고 시간당 탈질율을 분석하 였다(Fig. 7). 그 결과 외부 탄소원이 공급되지 않은 경우 잔존 유기물과 endogenous respiration 
Table 1. Characteristic of swine wastewater used in experiment

\begin{tabular}{lccccc}
\hline $\begin{array}{c}\text { Parameter } \\
(\mathrm{mg} / \mathrm{L})\end{array}$ & Means & Min & - & Max & St.Dev \\
\cline { 2 - 5 } $\mathrm{TOC}$ & 402.88 & 275.90 & - & 689.70 & 110.56 \\
$\mathrm{NH}_{4}-\mathrm{N}$ & 782.37 & 570.52 & - & 1138.50 & 119.65 \\
$\mathrm{NOx}-\mathrm{N}$ & 0.67 & 0.00 & - & 19.74 & 2.65 \\
$\mathrm{PO}_{4}{ }^{3-}$ & 35.36 & 7.63 & - & 66.03 & 15.39 \\
$\mathrm{TS}(\mathrm{g} / \mathrm{L})$ & 2.35 & 1.63 & - & 3.96 & 0.45 \\
$\mathrm{TVS}(\mathrm{g} / \mathrm{L})$ & 0.93 & 0.43 & - & 2.29 & 0.31 \\
$\mathrm{SS}(\mathrm{g} / \mathrm{L})$ & 0.27 & 0.08 & - & 0.52 & 0.09 \\
$\mathrm{VSS}(\mathrm{g} / \mathrm{L})$ & 0.28 & 0.18 & - & 0.52 & 0.07 \\
\hline
\end{tabular}

에 의한 탈질율은 약 $0.4 \mathrm{mg} / \mathrm{L} . \mathrm{hr}$. 정도로 매우 낮음을 알 수 있었다. 시험된 $\mathrm{C} / \mathrm{N}$ 비 $0.64,1.33$, 2.32. 4.78에서의 $\mathrm{NO}_{\mathrm{x}}-\mathrm{N}$ 제거율은 각각 1.73 , 1.93, $1.81,1.83 \mathrm{mg} / \mathrm{L} . \mathrm{hr}$ 로 (Fig. 7a) 큰 차이가 없는 것으로 나타났으나 Fig. $7 \mathrm{~b}$ 에서와 같이 $\mathrm{C} / \mathrm{N}$ 비가 1.3 이상인 경우에는 5 시간 때에 완전 한 탈질을 얻을 수 있는 반면 $\mathrm{C} / \mathrm{N}$ 비 0.64 의 경 우에는 6시간에서도 완전한 탈질이 일어나지 않았으며 4시간 이후의 $\mathrm{NO}_{\mathrm{x}} \mathrm{-N}$ 제거율이 잔존 유기물 이용 및 endogenous respiration에 의한 제거율과 거의 비슷한 수준으로 감소함을 알 수 있었다. 이러한 결과로 미뤼 판단할 때 $\mathrm{TOC} / \mathrm{NO}_{\mathrm{x}}-\mathrm{N}$ 비 0.64 수준의 경우 4시간 정도부 터 잔존 탄소원이 고갈되기 시작하여 반응조내 탈질과정이 주로 미생물의 endogenous respiration에 의존하기 때문에 $\mathrm{C} / \mathrm{N}$ 비 0.6 이하의 수준 에서는 빠른 완전탈질을 기대하기 어려움을 알 수 있었다.

실제 제거된 $\mathrm{NO}_{\mathrm{x}}-\mathrm{N} \mathrm{mg}$ 당 $\mathrm{TOC}$ 소모율을 분 석한 결과 $\mathrm{C} / \mathrm{N} 0.64,1.33,2.32,4.78$ 에서 각각 $1.48,1.64,1.9,2.13 \mathrm{mg}$ 으로 $\left(\mathrm{r}^{2}=0.9346\right)$ 초기 $\mathrm{C} / \mathrm{N}$ 비가 높을수록 $\mathrm{NO}_{\mathrm{x}}-\mathrm{N}$ 탈질에 비례적으로 많은 유기물이 소모되었음을 알 수 있었다. 이 러한 결과는 감소한 $\mathrm{TOC}$ 모든 양이 denitrifier
의 에너지원으로 사용된 것은 아니며 여분의 탄소원은 미생물 성장 및 다른 대사과정에도 이용되었던 것으로 판단된다. 아울러 교반 중 탄소원의 휘발로 인한 TOC의 감소가 발생함을 알 수 있었으며 methanol 첨가량 $\mathrm{ml} / \mathrm{L}$ 당 $\mathrm{TOC}$ volatilization rate/h는 약 1.418 인 것으로 분석되 었다. 본 data를 이용, 외부탄소원 적정 공급량 결정 조건을 첫째, 탈질 완료후의 $\mathrm{TOC}$ 농도가 외부 탄소원이 첨가되지 않은 경우와 비교하여 높지 않아야 하며 즉, 첨가된 모든 $\mathrm{TOC}$ 가 탈 질 과정에서 완전히 고갈되어야 하며, 둘째 완 전한 탈질을 얻을 수 있고 탈질율에 영향을 미 치지 않는 최소량 이어야 한다고 설정하여 endogenous respiration에 의한 탈질율과 safty factor 0.1 을 적용하여 도출한 결과 적정 외부탄소원 공급량을 위한 지표로 TOC loading/ $\mathrm{NO}_{\mathrm{x}}-\mathrm{N}$ 은 0.83 이 적정함을 알 수 있었다.

$$
\text { IV. 요 약 }
$$

다양한 조건하에서 가축분뇨처리공정을 운전 하면서 각 자동제어 인자의 반응을 분석하고 $\mathrm{ORP}, \mathrm{DO}, \mathrm{pH}(\mathrm{mV})$-time profile를 이용한 자동제 어 신뢰성을 평가하였다. 또한 무산소 조건에 
서의 잔존 유기물 및 미생물 자기산화에 의한 탈질율을 고려한 적정 외부탄소원 공급량 지표 를 파악하였다. 실험은 $45 \mathrm{~L}$ 의 유효용적을 지닌 실험실 규모의 SBR 공정을 이용하여 수행되었 다. ORP-와 $\mathrm{pH}(\mathrm{mV})-$, DO-time profile 상에서 완전질산화를 의미하는 $\mathrm{NBP}$ 가 뚜렷하게 발현 하던 중 $\mathrm{NH}_{4}-\mathrm{N}$ 의 낮은 부하와 고농도 $\mathrm{NO}_{\mathrm{x}}-\mathrm{N}$ 함유 폐수의 유입 및 불충분한 무산소 조건 제 공이 이루어졌을 때 ORP-와 DO-time profile 상 에서 $\mathrm{NBP}$ 가 사라지기 시작하였으며 $\mathrm{NO}_{\mathrm{x}}-\mathrm{N}$ 의 지속적인 증가에 의해 $\mathrm{ORP}$ 값의 민감성이 둔 화되기 시작하였다. 그러나 $\mathrm{pH}(\mathrm{mV})$-time profile 은 항상 일정한 변화패턴을 유지하면서 암모니 아성 질소의 완전 질산화가 이루어졌을 때 뚜 렷한 $\mathrm{NBP}$ 를 발현하였다. $\mathrm{NO}_{\mathrm{x}}-\mathrm{N} / \mathrm{NH}_{4}-\mathrm{N}$ 의 비가 80:1 수준까지 높아지는 조건하에서도 $\mathrm{pH}(\mathrm{mV})$ time profile상에서의 이러한 안정적 $\mathrm{NBP}$ 의 발 현은 지속되었으며 발현되는 $\mathrm{NBP}$ 는 $\mathrm{MSC}$ (Moving Slope Change)의 변화 패턴을 추적함에 의해 인식되도록 프로그램 할 수 있었다. $\mathrm{pH}$ (mV)-time profile에서의 NBP의 발현과 MSC를 이용한 자동제어시점 인식은 반응조내 $\mathrm{NO}_{\mathrm{x}}-\mathrm{N}$ 농도가 무려 $300 \mathrm{mg} / \mathrm{L}$ 이상의 수준에서도 안정 적이었다. 유기물 농도에 따른 자동제어 인자 의 반응을 분석한 시험에서도 반응조내 유기물 의 농도가 STOC 기준 약 $10,000 \mathrm{mg} / \mathrm{L}$ 수준으 로 증가함에도 불구하고 $\mathrm{pH}(\mathrm{mV})$-time profile 상에서의 이러한 NBP 발현은 지속되었으며 고 농도 유기물 축적 하에서도 동일한 자동제어 알고리즘이 이용될 수 있음을 알 수 있었다. 잔존 유기물과 미생물 자기산화에 의한 탈질율 은 약 $0.4 \mathrm{mg} / \mathrm{L} . \mathrm{hr}$ 로 분석되었으며 안전지수 0.1 을 도입하여 산출된 $\mathrm{NO}_{\mathrm{x}} \mathrm{-N}$ 기준 적정 외부탄 소원 공급량은 $0.83 \mathrm{STOC} / \mathrm{NO}_{\mathrm{x}} \mathrm{-N}$ 으로 파악되었 다.

$$
\mathrm{V} \text {. 사 사 }
$$

본 연구는 2003년도 ARPC (agricultural R\&D Promotion Center) 첨단기술개발과제 연구비 지
원에 의해 수행되었으며 이에 감사드립니다. 또한 강원대학교 동물자원공동연구소 기자재 지원에 감사드립니다.

\section{VI. 인 용 문 헌}

1. 김원용, 정재현, 라창식. 2004 . 생물학적 축산폐 수 처리공정의 자동제어 방법 및 제어인자의 안 정성. 동물자원과학회지, 46(2):251-260.

2. Akin, B. S. and Ugurlu, A. 2005. Monitoring and control of biological nutrient removal in a sequencing batch reactor, Process Biochemistry, 40:2873-2878.

3. Chen, K. C., Chen, C. Y., Peng, J. W. and Houng, J. Y. 2002. Real-time control of an immobilized-cell reactor for wastewater treatment using ORP, Wat. Res., 36:230-238.

4. Kim, J. H., Chen, M., Kishida, N. and Sudo, R. 2004. Integrated real-time control strategy for nitrogen removal in swine wastewater treatment using sequencing bstch reactors. Wat. Res., 38: 3340-3348.

5. Kishida, N., Kim, J., Chen, M., Sasaki, H. and Sudo, R. 2003. Effectiveness of oxidationreduction potential and $\mathrm{pH}$ as monitoring and control parameters for nitrogen removal in swine wastewater treatment by sequencing batch reactors, Bioscience and bioengineering, 96(3):285-290.

6. Marsili, L. S. 2006. Control of SBR switching by fuzzy pattern recognition. Wat. Res., 40:10951107.

7. Peng, Y. Z., Ma, Y. and Wang, S. Y. 2006. Improving nitrigen removal using on-line sensors in the A/O process, Biochemical Eng., 31:48-55.

8. Ra, C. S., Lo, K. V., Shin, J. S., Oh, J. S. and Hong, B. J. 2000. Biological nutrient removal with an internal organic carbon source in piggery wastewater treatment. Wat. Res., 34(3):965-973.

9. Ra, C. S., Lo, K. V. and Mavinic, D. S. 1999. Control of a swine manure treatment process 
Park and Ra ; Reliability of Real-time Control Parameters for Animal Wastewater Treatment Process

using a specific feature of oxidation reduction potential, Bioresource technology, 70:117-127.

10. Ra, C. S., Lo, K. V. and Mavinic, D. S. 1998. Real-time control of two-stage sequencing batch reactor system for the treatment of animal wastewater. Environmental Techology., 19:343-356.

11. Yu, R. F., Liaw, S. L., Chang, C. N., Lu, H. J. and Cheng, W. Y. 1997. Monitoring and control using on-line ORP on the continuous flow activated sludge batch reactor system, Wat. Sci. Tech., 35(1):57-66.

12. Zhang, Z., Zhu, J., King, J. and Li, W. 2006. A two-step SBR for treating swine manure, Process Biochemistry, 41:892-900.

(접수일자 : 2008. 1. 10. / 수정일자: 2008. 7. 8. / 채택일자 : 2008. 8. 14.) 